\title{
Edgar Morin, educação e complexidade: para além do pragmático, o paradigmático
}

\author{
Maria da Conceição de Almeida* - UFRN \\ Eugenia Maria Dantas* - UFRN
}

\section{Resumo}

Edgar Morin é considerado o formulador de uma epistemologia da complexidade, artífice do pensamento complexo, da reforma do pensamento e um dos propositores da reforma da educação em bases transdisciplinares. Mais do que uma proposta de natureza programática, a noção de educação para a complexidade se pauta por princípios epistemológicos e meta-temas capazes de se desdobrar em saberes que religam a tríade indivíduo-sociedade-espécie. Este artigo apresenta um panorama alargado da emergência das ciências da complexidade em Edgar Morin, emergência no interior da qual se situa sua aposta na educação. É também um produto parcial dos estudos e pesquisas das autoras em torno da obra de Edgar Morin ao longo de mais de duas décadas. Daí porque se recorre aqui a fragmentos de produções anteriores das autoras, bem como aos registros de suas aulas expositivas nos Ateliês Educação e Complexidade oferecidos regularmente no Programa de Pós-Graduação em Educação da UFRN.

Palavras-chaves: Educação. Complexidade. Reforma do ensino. Religação de saberes.

Doutora em Ciências Sociais (Antropologia) pela PUC-SP. Atualmente é Professora Titular da Universidade Federal do Rio Grande do Norte, atuando junto aos Programas de Pós-Graduação em Educação e Programa de Pós-Graduação em Ciências Sociais. Coordenadora do Grupo de Estudos da Complexidade - GRECOM. Membro da Association pour la Pensée Complexe - Paris.calmeida17@hotmail.com

** Doutora em Educação pela Universidade Federal do Rio Grande do Norte. Pós-Doutorado no Grupo de Estudos da Complexidade (GRECOM/ UFRN) com ênfase na abordagem Mestiça de Michel Serres. Atualmente é Professora Titular da Universidade Federal do Rio Grande do Norte, atuando junto aos Programas de Pós-Graduação em Geografia e Colaboradora Voluntária do Pós-Graduação em Educação. Pesquisadora do Grupo de Estudos da Complexidade-GRECOM. eugeniadantas@yahoo.com.br 


\section{Edgar Morin, education and complexity: beyond the pragmatic, the paradigmatic}

\section{Abstract}

Edgar Morin is considered the designer of an epistemology of complexity, architect of complex thinking, and of the reform of thought. He is one of the proponents of education reform on transdisciplinary bases. More than a proposal of a programmatic nature, the idea of education for complexity is guided by epistemological principles and meta-themes capable of unfolding in knowledge that reconnect the triad: individuals-society-species. This article presents a broad overview of the emergence of the sciences of complexity in Edgar Morin, where his bet on education is located. It is also a portion of the authors' studies and research on Edgar Morin's work throughout more than two decades, reason why the reader will find here fragments of the authors' previous productions, as well as records of their lectures in the Education and Complexity Workshops, which are regularly offered in the Graduate Program in Education at UFRN.

Keywords: Education. Complexity Education reform. Reconnection of knowledge.

\section{Edgar Morin, educación y complejidad: Más allá de lo pragmático, lo paradigmático}

\section{Resumen}

Edgar Morin es considerado el formulador de una epistemología de la complejidad, artífice del pensamiento complejo, de la reforma del pensamiento, y uno de los impulsores de la reforma de la educación sobre bases transdisciplinarias. Más que de una propuesta de naturaleza programática, la noción de educación para la complejidad se orienta por principios epistemológicos e meta-temas capaces de desdoblarse en saberes que religan la triada individuo-sociedad-especie. En este artículo es presentado un panorama ampliado de la emergencia de las ciencias de la complejidad en Edgar Morin, emergencia en cuyo interior se sitúa su apuesta en la educación. Es también un producto parcial de los estudios e investigaciones de las autoras en torno de la obra de Edgar Morin a lo largo de más de dos décadas. Es por eso que se recurre aqui a fragmentos de producciones anteriores de las autoras, así como también a los registros de sus clases expositivas en los Ateliês Educação e Complexidade desarrollados regularmente en el Programa de Posgrado en Educación de la UFRN.

Palabras Clave: Educación. Complejidad. Reforma de la Enseñanza. Religación de Saberes. 


\section{Introdução}

Evitar a armadilha de que para dar conta de um tema precisamos ir direto ao assunto de modo analítico e pragmático parece ser um alerta do pensamento complexo. Em a Cabeça bem-feita, falando sobre o "conhecimento pertinente", diz Edgar Morin: "o conhecimento pertinente é o que é capaz de situar qualquer informação em seu contexto e, se possível, no conjunto em que está inscrita. Podemos dizer até que o conhecimento progride não tanto por sofisticação, formalização e abstração, mas, principalmente, pela capacidade de contextualizar e englobar" (MORIN, 2004, p. 15). Seguindo esse alerta comecemos por situar o contexto científico de emergência da complexidade e os princípios maiores que transpassam a obra de Edgar Morin antes de chegar ao âmago de sua compreensão, propostas e reflexões sobre educação, religação dos saberes e reforma do ensino.

Essa escolha tem o propósito de evitar a simplificação que ocorre quando se faz a leitura dos escritos direcionados mais para a educação, como em Os sete saberes necessários à educação do futuro (MORIN, 2000), dissociando-os de A cabeça bem-feita: Pensar a reforma, reformar o pensamento (MORIN, 2004). De fato, a compreensão do que seja, para Morin, a religação dos saberes e sua necessária compreensão da inadiável reforma da educação (do ensino fundamental às universidades) supõe a leitura conjunta dos dois livros referidos e não apenas de um. E mais. Requer não separar essa temática do itinerário epistemológico de sua obra. Mesmo porque em $A$ cabeça bem-feita: Pensar a reforma, reformar o pensamento o autor expõe cenários argumentativos e fundamentos epistemológicos que complementam o livro sobre Os sete saberes. É importante assinalar que os dois livros são publicados em Paris no mesmo ano de 1999 e devem ser entendidos, portanto, como obras singulares, mesmo que se complementem. Compreendemos que esse alerta contribui para retotalizar as investidas feitas por pedagogos e educadores, que, separando os dois livros, e priorizando Os sete saberes, caminham na direção de buscar lições pragmáticas ou 'ferramentas aplicáveis' à reformulação 
curricular de cursos universitários ou à elaboração dos Projetos Pedagógicos no ensino básico. De fato, a hegemonia do pragmatismo está na contramão das ideias de Morin sobre educação e "ensino-educativo", conforme suas palavras no prefácio d'A Cabeça bem-feita: "a missão do didatismo é encorajar o autodidatismo, despertando, provocando, favorecendo a autonomia do espírito" (MORIN, 2004, p. 11). Dito de outra forma: "Trata-se de uma reforma não programática, mas paradigmática, concernente a nossa aptidão para organizar o conhecimento" (MORIN, 2004, p. 20).

Em síntese o presente texto procura deixar claro que a compreensão de educação e ensino para Edgar Morin é parte de um

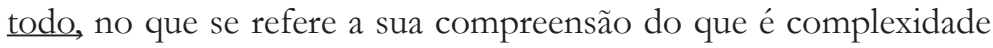
e conhecimento.

\section{Panorama da emergência das ciências da comple- xidade}

Os apelos do pensamento complexo sugerem uma atitude dialogal diante dos fenômenos e não apenas uma postura estritamente analítica; acolhem o paradoxo, a incerteza e o inacabamento como propriedades dos fenômenos ditos complexos; defendem a ideia de que o pesquisador interfere na realidade; reconhecem o erro como constituinte do ato de conhecer; assinalam que é tênue o limite entre realidade, ilusão e ficção, e que as interpretações e teorias são sempre $\underline{\text { mais, }}$ ou menos, que os fenômenos aos quais se referem. Tais apelos e indicações devem ser vistos hoje como um novo estilo cognitivo na construção do conhecimento, da educação, da vida.

A partir do final do século XIX, com a intensa comunicação entre os continentes, ocorre um verdadeiro big-bang na produção de informações e uma aceleração na circulação das ideias, teorias e interpretações. Fruto disso é o protagonismo da ciência como uma linguagem universal, apta a criar elos importantes para a mundialização em curso e, consequentemente, para seu desdobramento em áreas disciplinares distintas. A consciência de que o conhecimento científico opera de forma ambígua, contraditória e paradoxal que- 
brou as fronteiras geográficas entre nações e continente, mas ao mesmo tempo recriou barreiras físicas e imaginárias em torno de disciplinas cada vez mais especializadas. Se hoje é mais difícil identificar um único criador para cada nova interpretação dos fenômenos - haja vista o trânsito intenso das ideias no contexto da mundialização - é também, via de regra, mais sofisticada a hiper-especialização que confina o cientista e seus saberes no interior de um mesmo território disciplinar.

As ciências da complexidade emergem como uma bifurcação nesse cenário gestado entre os séculos XVIII e XIX. Se fosse possível fazer um exame do DNA dessas ciências anunciaria o estranho resultado de uma maternidade/paternidade múltipla, polifônica, difusa, talvez mesmo promíscua. Entretanto, dois físicos-filósofos merecem destaque no contexto dessa nova reorganização dos conhecimentos. Nos primeiros anos do século XX, o dinamarquês Niels Bohr (18851962) discutirá a ambiguidade como uma característica evidenciada pela matéria quando se observa alguns fenômenos, concebidos como complexos. Para Bohr, diante das expressões distintas de um mesmo fenômeno torna-se impeditivo para as ciências descrever com exatidão sua dinâmica sendo, portanto, inadequado dizer 'isto é assim'. Ao lidar com as ambiguidades, as ciências devem anunciar agora: 'dadas essas circunstâncias de apresentação do fenômeno, é isto que posso dizer' (BOHR apud HEISENBERG, 1996). Essa constatação possibilitou Bohr formular o princípio da complementaridade. De sua parte, em 1926 o alemão Werner Heisenberg (1901-1976) propõe o princípio da incerteza que, em conjunto com a noção de ambiguidade e descontinuidade dos fenômenos, formam como que um quebra-cabeça para a emergência posterior de um método complexo construído por Edgar Morin. Em alguns de seus livros, e sempre que trata da nova reorganização do conhecimento em bases complexas e transdisciplinares, Edgar Morin reconhece em $O$ novo espirito científico de Gaston Bachelard a formulação original da noção de complexidade como um vetor epistemológico de bifurcação em relação ao paradigma cartesiano. 
É densa e matizada a argumentação de Bachelard na Introdução de $O$ novo espírito científico, publicado na França em 1934. Ali ele afirma que assistimos ao "florescimento de línguas novas", a superação dos dualismos objetivo/subjetivo, determinismo/indeterminismo; que "o pensamento científico pode atuar em termos opostos, indo do euclidiano ao não-euclidiano" por meio de "matemáticas alargadas" e uma "pangeometria". Tendo, como sempre, seu foco na docência e na pesquisa, propõe o que chama de "uma espécie de pedagogia da ambiguidade" capaz de nutrir o espírito científico da "flexibilidade" necessária para lidar com o complexo. Bachelard se interroga se "a epistemologia cartesiana, toda ela apoiada na referência às ideias simples, pode bastar para caracterizar o pensamento científico atual" (BACHELARD, 2008, p. 11). Em síntese, e convicto de que a compreensão da complexidade dos fenômenos inaugura um novo paradigma nas ciências, diz:

Tentaremos, então, na conclusão filosófica do nosso trabalho, apresentar as características de uma epistemologia não-cartesiana que nos parece consagrar verdadeiramente a novidade de espírito científico contemporâneo. [...] E essa novidade é profunda porque não é a novidade de uma descoberta, mas a novidade de um método (BACHELARD, 2008, p.13).

A formulação da noção de complexidade por Bachelard vai se consubstanciando e ganhando consistência na medida em que, para Edgar Morin, começam a se dissolver os 'quatro pilares da certeza' que sustentavam a ciência 'clássica': os princípios da Ordem, da Separabilidade, da Redução e da Lógica indutiva-dedutiva-identitária. A dissolução desses pilares, longe de se configurar numa axiomática própria das construções teóricas abstratas, é fruto do processo de interconexões geográficas, políticas e culturais levadas a efeito pela sociedade-mundo, em âmbito planetário.

Em meio ao big-bang dos avanços do conhecimento e à crise dos princípios que norteavam a ciência clássica, coube a Edgar Morin assumir o desafio de construir um método capaz de religar e fazer dialogar as várias descobertas oriundas de áreas distintas. 
Com isso pode ele propor um método como estratégia que, a partir de princípios gerais, pode ser acionado por qualquer área do conhecimento. Se, pois, as ciências da complexidade não têm pater-maternidade definida, o método complexo tem, em Edgar Morin, seu artífice e construtor. O método complexo tem como base e fundamento a perspectiva transdisciplinar ultrapassando as metodologias inter e multidisciplinares.

\section{Complexidade: desafio e método de pensar}

A ideia de complexidade é, para Edgar Morin, uma palavra problema e não uma solução. Não deveria se encerrar nos compêndios acadêmicos, mas "chegar às ruas e às praças", como costuma afirmar ele. O intelectual acadêmico e o educador não são mais entendidos somente como aqueles que dominam muito bem o fenômeno do qual tratam, mas também sujeitos ativos que se posicionam frente aos problemas do seu tempo. Disso trata o autor em seu livro Meus demônios (1995), no capítulo intitulado "Uma experiência intelectual".

Desalojar-se dos estreitos limites da superespecialização para compreender a complexidade dos fenômenos do mundo é condição necessária (mesmo que não suficiente) para responder aos complexos problemas políticos, ecológicos, educacionais e sociais em níveis locais e planetários.

Podemos sintetizar aqui alguns tópicos estruturantes do que poderia ser uma matriz incompleta da noção de complexidade tópicos esses que aparecem contextualizados e problematizados em uma publicação anterior (ALMEIDA, 2017): complexidade não é complicação; comporta incertezas; há níveis diferenciais de complexidade; o complexo é marcado pela imprevisibilidade, instabilidade, não-linearidade e inacabamento; os sistemas complexos sofrem metamorfoses, auto-eco-organização e se instalam longe do equilíbrio; por consequência, todo fenômeno complexo é simultaneamente autônomo e dependente, uma vez que vive da tensão entre determinismos e liberdade ; se caracteriza-se também por ser 
sensível a flutuações, provocar emergências, bifurcações, e induzir tendências e probabilidades.

A identificação desses tópicos, categorias e princípios situa a complexidade entre o que é inerente a determinados fenômenos e o que alimenta a estratégica do método complexo. O panorama das reflexões sobre as ciências hoje, especialmente por parte de Edgar Morin, requer, pois, a construção de estratégias cognitivas abertas ao diálogo com a realidade.

Reconhecendo isso, o cientista-educador opera com a ambígua e ambivalente tarefa de elaborar narrativas implicadas na recursividade, no diálogo possível entre as descrições dos fenômenos (a partir de como eles aparecem), suas propriedades, e as condições das quais dispõe o narrador. Esse parece ser o horizonte comum das ciências da complexidade (ALMEIDA, 2017) e que, em Morin, assume o lugar epistemológico de um pensamento sem fronteiras.

Alguns metaprincípios e operadores cognitivos subjazem ao conjunto da obra de Edgar Morin: a implicação do sujeito no conhecimento; uma eco-antropologia fundamental; uma ecologia das ideias e da ação; e a indissociabilidade entre os domínios da matéria, da vida, da humanidade, da cultura e das ideias. Entendemos serem esses os operadores cognitivos que oferecem a sustentação e ao mesmo tempo a incerteza e o inacabamento de uma epistemologia de base complexa.

\section{Um pensador sem fronteiras}

Além de Um amor bandido (escrito aos nove anos e cujo exemplar único se encontrava numa biblioteca em Paris), a obra de Edgar Morin tem sido indexada como: títulos de conjuntura; títulos classificados como sociologia, antropologia, política, cultura de massa e cinema; diários e "autobiografias"; títulos sobre ciência e conhecimento ${ }^{1}$.

O ano zero da Alemanha (1946), seu primeiro livro. A seguir, sem ordem cronológica, editora e os respectivos subtítulos, citamos as principais publicações traduzidas para o português: Cultura e Barbárie Europeia; A via; 
A obra central, e pela qual é reconhecido como o propositor de um método científico que inaugura um novo paradigma após René Descartes, se intitula $O$ Método, em seis volumes ( $A$ natureza da natureza; $A$ vida da vida; $O$ conhecimento do conhecimento; As ideias; $A$ bumanidade da humanidade; e Ética).

A publicação de O Método tem início em 1977, mas já está anunciada em O Paradigma Perdido (1991), publicado em Paris em 1973. Construído ao longo de 27 anos (1977 a 2004), os seis volumes de $O$ Método, de fato, desdobram, por meio dos metatemas (natureza, vida, conhecimento, ideias, humanidade e ética), concepções retotalizadoras da condição humana na Terra, cujas matrizes estão no Paradigma perdido, a saber: a $\underline{\text { ideia de simbiose e relação }}$ indissociável entre a espécie humana e o ambiente, reconhecida por Morin como formulada por pensadores anteriores a ele, entre os quais Karl Marx, no Manuscrito de 1844; a ideia de uma ecologia social construída pela tríade espécie-indivíduo-sociedade, marcada por especializações importantes fruto da experiência humana; a importância dos desvios (pré-bióticos, bióticos e culturais) que se tornam regra posteriormente, e as ampliações substantivas de níveis da complexidade organizacional, notadamente pela emergência da psique, do surgimento de uma dupla consciência, objetiva e subjetiva, que se parasitam mutuamente e se complementam; e, por fim, a noção de cultura como sistema generativo-regenerativo aberto, simultaneamente biológico, antropológico, social e históri-

Rumo ao Abismo; Terra-Pátria (com Anne Brigitte Kern); Uma política de Civilização; Para um Pensamento do Sul; Sociologia; Para uma política do homem; Cultura de massa no século XX (Necrose; Neurose); As estrelas; $\mathrm{O}$ cinema ou o Homem Imaginário; $\mathrm{O}$ paradigma Perdido; $\mathrm{O}$ homem e a morte; Vidal e os seus; Meus filósofos; Minha esquerda; Meus Demônios; Minha Paris, minha memória; Amar, chorar, rir, compreender; O diário da Califórnia; Diário da China; Um ano sisifo; Meus Filósofos; O X da questão; Minhas Paris; Meu Caminho; Edwige, a inseparável; Introdução ao pensamento complexo; Para sair do século XX; Ciência com consciência; A inteligência da complexidade (com J. Louis Le Moigne); A aventura do método; Religar os conhecimentos; A cabeça bem-feita; Os sete saberes necessários à educação do futuro; Ensinar a viver; Sobre a estética. 
co, marcado pelo inacabamento, acaso, tensão, criação, incertezas e, sobretudo, pela ambiguidade entre real e imaginário.

Longe de se restringir à razão e à habilidade técnica, o processo de construção e formação do sujeito anunciado no Paradigma Perdido lança as bases para a compreensão de que a "educação é um operador de aprendizagem da cultura” (ALMEIDA, 2017, p. 79). Imerso na imitação e repetição da regra cultural coletiva, a formação do sujeito se vale também da inventividade, da contestação ao estabelecido, do desafio diante do imponderável e das imaginações fantásticas para repor os estoques de humanidade e criar novos mundos, novas interpretações, novas utopias. Essa compreensão transpassa toda a obra de Edgar Morin, seja em seus livros classificados como obras sobre ciência, seja naqueles considerados de conjuntura ou educação. Nada mais esperado, a esse respeito, do que o tom da dedicatória que abre o livro $A$ cabeça bem-feita: "Este livro é dirigido a todos, mas poderia ajudar particularmente professores e alunos. Gostaria que estes últimos, se tiverem acesso a esse livro, e se o ensino os entedia, desanima, deprime ou aborrece, pudessem utilizar meus capítulos para assumir sua própria educação" (MORIN, 2004). Essa ode a inventividade e ao desejo de se instituir como sujeito de sua própria criação imaginativa certamente está na defesa de uma educação que seja capaz de restaurar Eros nas escolas e universidades. "A finalidade da reforma da educação, que não é outra senão "o bem viver de cada um e de todos, principalmente dos professores e alunos, requer de ambas as partes a regeneração de Eros", escreve ele na conclusão de seu livro Ensinar a viver: manifesto para mudar a educação (MORIN, 2015, p. 180).

Para Morin, o homem deixou de ser entendido como Sapiens-sapiens e passa a ser compreendido como Sapiens-demens. E, mesmo que o paradigma humano conjugue repetição e variação, ordem e desordem, sabedoria e loucura, é à porção demens, sobretudo, que se devem os saltos em complexidade mais significativos. Na obra do autor, o destaque para o demens aparece, por exemplo, na terceira parte de $O$ Paradigma com o título "Um animal dotado de despropó- 
sito” (MORIN, 1991 p. 91); e no Método 5 (2002) no Capítulo 4 da Segunda parte, com o título "O complexo de Adão. Sapiens-demens" (MORIN, 2002, p. 115).

Desvios, ruídos, inventividade, pulsão de criação e desordens são propriedades e ingredientes bioculturais impulsionadores de dinâmicas distintivas nos sistemas auto-organizados complexos. Entretanto, no interior do mesmo processo de complexificação coabitam forças de regressão e comprometimento de complexidade. Assim, algumas experiências humanas que são expostas como alavancas de novas reorganizações, são problematizadas com mais vigor nos volumes do Método para demonstrar regressões em complexidade.

A esse respeito, referimo-nos a três exemplos que dizem respeito à ambivalência do fenômeno da especialização e que remetem a experiências primordiais da espécie humana aludidas por Edgar Morin no Paradigma perdido: os deslocamentos dos homens adultos para a caça; os adolescentes com tempo livre para criar; e as mães com seus filhos ao seio para a amamentação por um longo tempo. Para Morin, por hipótese, essas três experiências arcaicas são responsáveis pela emergência dos fenômenos da solidariedade, da inventividade e da amizade, impostos ou facilitados pelos perigos da caça (no caso dos homens adultos); pela curiosidade e criatividade (no caso dos adolescentes, que, para o autor, foram os responsáveis pela criação do fogo); e pela emergência de uma semiótica do afeto e aprendizagem do amor (no caso das mães nos longos período de amamentação, que caracteriza as primeiras sociedades).

Esses três novos fenômenos (solidariedade, inventividade e amor) que complexificam a condição humana nas sociedades arcaicas - fruto da experimentação de três "classes" distintas (palavra usada por Morin) - acabam por constituir uma ecologia comum a toda a sociedade. Ora, como sabemos, nas sociedades modernas - e no que diz respeito em particular à construção das ciências e a educação -, as especializações se degeneram em práticas esotéricas que impedem ou dificultam a troca e diálogo entre áreas 
de conhecimento e a diversidade de experiências culturais. Dessa perspectiva, a fragmentação dos conhecimentos é a face necrosada da especialização não comunicante, portanto, é regressão de complexidade. Essa constatação torna a obra de Morin uma pista desafiadora para escolas, governos, universidades, educadores. Da parte dos educadores em relação aos adolescentes, o pragmatismo da formação que, desde cedo, leva os estudantes a repetir o que está nos livros didáticos, desestimula e mesmo impede as condições de criatividade, e esse é outro exemplo de regressão em complexidade da condição humana.

\section{Do pragmático ao paradigmático: a reforma da educação.}

Importante destacar que os títulos direcionados diretamente à educação aparecem no final dos anos de 1990, depois de toda a investida do autor em várias temáticas e em particular na construção de um método capaz de religar as ciências da natureza, da vida e do homem. Tudo se passa como se aflorasse em Edgar a consciência de que é no início da formação que as crianças e adolescentes podem ser instados a religar todas as coisas do mundo. Daí porque, como já dito, os primeiros livros sobre a reforma do ensino fundamental são publicados (em Paris) em 1999.

Os sete saberes necessários à educação do futuro (2000), A cabeça bem-feita (2004), A religação dos saberes (2001), Educar na era planetária, em parceria com Ciurana e Motta (2003) e Ensinar a viver (2015) expressam seu compromisso explícito com a educação, com uma necessária reforma da educação, reforma essa predominantemente paradigmática - sem excluir o pragmático, claro. O que ensinar nas escolas? Como articular entre si os conteúdos específicos das disciplinas? Quais os grandes temas e valores capazes de mobilizar uma atitude mais ética diante do mundo? Essas são questões antigas, mas sempre atuais, quando postas de uma perspectiva paradigmática. Para Morin, uma reforma dessa natureza está circunscrita a mudança na estrutura de pensar, 
que permite enfrentar o extraordinário desafio que nos encerra na seguinte alternativa: ou sofrer o bombardeio de incontáveis informações que chovem sobre nós, cotidianamente, pelos jornais, rádios, televisões; ou então entregarmo-nos a doutrinas que só detêm das informações o que as confirma ou o que lhes é inteligível, e refugam como erro ou ilusão tudo o que as desmentem ou lhes é incompreensível (MORIN, 2004, p. 20).

Inspirado no diálogo de Marx (2010) com a Feuerbach, sobre quem educará os educadores, e na ideia de Montaigne, de que "mais vale uma cabeça bem-feita que bem cheia", Edgar Morin assume o difícil desafio de propor uma reforma da educação e do ensino. Argumenta ele que, em vez de levar os estudantes a acumular informações devemos, como educadores, estimulá-los a construir uma aptidão geral para colocar e tratar os problemas. Em outras palavras, os professores devem atuar para que os estudantes, com liberdade e criatividade, possam lançar mão de princípios organizadores para tratar as informações, transformando-as em conhecimentos e, por fim, inseri-los num contexto maior (transdisciplinar) que lhes oferece sentido. É essa, para Edgar Morin, a concepção de "conhecimento pertinente" da qual trata, sobretudo, nos livros $A$ cabeça bem-feita e Os sete saberes necessários à educação do futuro.

A missão maior do educador é, portanto, fazer com que a educação favoreça e estimule

o pleno emprego da inteligência geral. Esse pleno emprego exige o livre exercício da faculdade mais comum e mais ativa na infância e na adolescência, a curiosidade, que muito frequentemente é aniquilada pela instrução, quando, ao contrário, trata-se de estimula-la ou despertá-la, se estiver adormecida. Trata-se, desde cedo, de encorajar, de instigar a aptidão interrogativa e orienta-la para os problemas da nossa condição e de nossa época. É evidente que isso não pode ser inserido em um programa, só pode ser impulsionado por um fervor educativo" (MORIN, 2004, p. 22).

Destituída das normatividades excessivas e dos protocolos bancários de acumular créditos que inibem a imaginação, as escolas e universidades poderiam se tornar espaços de aprendizagem aberta, que rompem com o predomínio da rigidez, da exatidão e 
da razão patológica que acabaram constituindo o século das Luzes como o marco principal de referência para a organização, sistematização e disseminação do saber, tal como conhecemos hoje. Por meio desses protocolos, os saberes e as experiências que não resistem ao teste da razão e da demonstração serão classificados como míticos, esotéricos, religiosos, transcendentais, metafísicos. Esse caminho representa na verdade fixações normativas excludentes de estados de ser do pensamento humano, em sua essência polivalente, polifônico, múltiplo.

Nas palavras de Morin, o intelectual moderno "descende de uma tradição muito antiga: a dos sacerdotes-magos, encarregados de anunciar a verdade sagrada, produtores/ guardiães dos mitos" (MORIN, 1986, p. 232). O filósofo iluminista passa a submeter a verdade sagrada à prova da crítica. Produz-se um novo mito: a razão. Dessa ruptura nasce o intelectual moderno e também o educador. "O mito da razão emancipa o intelectual", afirma ainda Morin em Para sair do Século XX (MORIN, 1986, p. 234).

Dotado de uma simbiótica ambivalência, o sábio pré-iluminista se constituía ao mesmo tempo como defensor de valores morais e um rigoroso observador, sistematizador e interpretador dos fenômenos físicos e sociais do seu tempo. O intelectual moderno emerge no interior de um matizado processo sócio-histórico que elege a razão como o único critério definidor da ciência. Mutatis-mutandis a transformação do educador, antes um sábio polivalente, hoje um especialista num domínio estrito de competência, reatualiza o mesmo processo de fratura e redução das condições ampliadas da comunicação do conhecimento.

Reprograma-se o pensamento pela via das escolhas redutoras entre homem e meio, razão e imaginação, crença e demonstração. As questões colocadas pelas sociedades passam a ter domínios de resolução distintos. $\mathrm{O}$ conhecimento como recurso para fechar a brecha cérebro-meio tem agora diante de si questões de natureza supostamente diferenciadas. Estabelecem-se divisores entre o que é da ordem do racional e do irracional, e, mais particularmente, 
opõem-se os problemas considerados ora míticos, ora metafísicos, ora científicos. A fragmentação do pensamento torna-se visível pela produção de especialistas não comunicantes. Emerge o descompasso na articulação entre os itinerários míticos e lógicos. O pensamento simplificador pulverizará a partir de então as questões a serem apreciadas pelas sociedades humanas de forma insular e pontual.

Essa estrutura de operação do pensamento e produção do conhecimento tem por base a emergência de uma sociedade pré-industrial que vê multiplicados os problemas já existentes ao mesmo tempo em que se defronta com o aparecimento de novos problemas. O aumento e deslocamento populacionais, o redirecionamento da formação técnico-profissional, o aparecimento de doenças provocadas pelas aglomerações urbanas etc., vão demandar uma nova organização na produção de saberes. Essas contingências sócio-históricas consolidarão várias cadeias de separação sucessivas entre natureza e cultura, o mundo real e o mundo imaginário, produção material e produção do pensamento, trabalho manual e trabalho intelectual, fazer e saber, teoria e prática, pensamento e ação. A separação entre a arte da técnica e a estética da reflexão encontrará na sociedade industrial nascente as condições favoráveis para expressar-se. Torna-se então indispensável à formação de competências específicas gestadas pelos adestramentos que confinam o indivíduo em um campo extremamente restrito de atividades. A ciência passa a acentuar o caráter utilitário do conhecimento, limitando o campo da reflexão a certos domínios. As universidades protagonizam-se formadoras de perfis intelectuais, científicos, educacionais especializados, e as escolas reproduzem esse modelo com jovens, adolescentes, crianças.

No cenário dessa lógica perversa, as instituições educacionais vão aos poucos abrindo mão da reflexão e da crítica para privilegiar a formação de especialistas que reproduzem maquinicamente uma sociedade fragmentada, comprometendo assim as condições de convivialidade e diálogo social entre os saberes milenares da tradição e a ciência moderna. 
Assim, em primeiro lugar, mais que reformular as teorias e metodologias particulares para pensar o mundo, é fundamental que nos coloquemos o problema de recompor a estrutura de pensar. Em segundo lugar, considerando o quadro interno do conhecimento científico, há que se propugnar pela articulação entre ciências da vida, ciências do homem, ciências do mundo físico. Aqui, não bastarão, certamente, esforços de superposição de conteúdos disciplinares. Nessa direção, a interdisciplinaridade deve ser ultrapassada pelo horizonte da transdisciplinaridade, em busca do pensamento complexo. Por outro lado, esse intercâmbio interno entre disciplinas científicas não basta. É fundamental ampliá-lo nos quadros do diálogo entre a ciência e os saberes da tradição, conforme já assinalamos.

Esses exercícios supõem reativar ou configurar uma estrutura cognitiva de múltiplas e complexas entradas. Nessa nova e plurifocal rede cognitiva perde sentido, certamente, a estrutura dual e fragmentada de pensar o mundo e o homem. Esse é o horizonte posto hoje ao conhecimento.

Diante deste horizonte é importante investir numa reorganização do conhecimento capaz de prover uma reforma na educação. Isso requer uma nova aliança entre cultura cientifica e cultura humanística, a reforma do pensamento e o exercício do diálogo. Essas ideias podem fomentar práticas educacionais capazes de religar os conhecimentos e fazer dialogar nossas competências. Rediscutir como hipóteses postulados tidos como indiscutíveis, imprimir importância a fatos concebidos como aleatórios pela ciência, refutar a ortodoxia e o maniqueísmo, por à luz nossas crenças fundamentais, exercitar a criatividade do pensamento, são alguns dos protocolos que favorecem a emergência de um novo espírito cientifico e de um novo educador.

Esse protocolo de intenções, talvez mais propriamente uma pedagogia da complexidade, precisa estar comprometido com um ideário educacional mais ético diante dos graves problemas planetários, sem abrir mão, é claro, da nossa herança milenar que, de uma certa forma, ainda se mantém nos redutos dos saberes da 
tradição. Esse desafio, longe de configurar uma missão própria de um especialista, pertence igualmente aos epistemólogos, físicos, educadores, sociólogos, antropólogos, intelectuais da tradição, pensadores indígenas.

\section{O educador, a que será que se destina?}

Educar é um ato de esperança e, como tal, regado pelo desejo de que o que foi plantado brote da melhor forma possível. Educar é um exercício de paciência, espera e incerteza. Educar é uma espécie de lapidação na perspectiva de um presente melhor do que o passado e sempre aquém do que o futuro pode moldar. Prefaciando o livro Júlio Verne: a ciência e o homem contemporâneo. Michel Serres: diálogos com Jean-Paul Dekiss, Jean-Paul Dekiss (2007) sintetiza, em certa medida, a esperança de Verne com o conhecimento e com a educação vistas sob essas lentes.

A última palavra é também aquela que Ray Bradbury põe na boca de Júlio Verne ao fim de sua conversa imaginária com ele. Depois de expressado uma vez mais a esperança de ver as gerações futuras mais bem educadas no conhecimento do que as precedentes Júlio Verne, antes de virar-se e desaparecer na praia deserta, conclui: 'Transmitam!'. (DEKISS, apud SERRES, 2007, p. 10)

Transmitir o que se sabe faz parte da orientação dada pelo escritor para bem educar, mas também, está na base do exercício pedagógico condutor dos humanos em sua travessia para o mundo da cultura. A narrativa pedagógica consiste de um volumoso enredo enciclopédico, resistente às transmutações temporais e espaciais, porque transversalizada pela questão: que homem queremos formar? Essa pergunta de caráter universal singulariza-se pelas variações narrativas que recobrem a superfície da Terra de um manto mesclado, tigrado, zebrado, misturado, mestiço, como sugere Michel Serres (1993). Esse manto torna-se o mapa das decifrações, não mais de uma questão original em si, mas do conjunto de sobreposições e entrelaçamentos realizados na tentativa de transmitir, de 
modo cada vez mais lapidar, conhecimentos múltiplos, sejam eles oriundos das populações tradicionais ou propriamente originados pelas ciências modernas. De uma perspectiva complexa, essa transmissão ocorre pelo reconhecimento de uma práxis educativa guiada, a priori, pelo trânsito entre estes conhecimentos e pela promoção do ensino-educativo da condição humana tecido na convergência dialógica entre as culturas cientificas e as culturas das humanidades.

A reforma da educação pressupõe pensar um educador capaz de lidar com questões do tipo: quais são os "saberes necessários à educação do futuro?”, como propugnada por Edgar Morin. Como reorganizar o que já acumulamos? Para avançar, é necessário abdicar de nossas especialidades? Não. O educador do mundo contemporâneo assume-se como um autor especial capaz de viajar, se deslocar da sua área de pertencimento para compartilhar experiências múltiplas, sempre munido pelo ideal de abrir as disciplinas, fazer dialogar as competências e as estruturas de pensar. Esse educador-autor se assemelha ao que Serres diz ter sido Júlio Verne na sua formação. Segundo Serres um autor é "alguém que aumenta; aquele que nos aumenta, que faz crescer o leitor ou que enriquece a matéria sobre a qual trabalha: o aumentador" (SERRES, 2007, p. 73). Para empreender tal exercício, podemos ter por espelho, novamente, o que diz Serres a respeito da pedagogia como um modelo baseado na viagem ou no deslocamento.

Quando os gregos, por exemplo, inventaram o ensino programado, a Paideia, o primeiro texto que deram à juventude foi a Odisseia. A que isso remetia? Remetia à questão: Que homem queremos formar? Todo mundo respondia: eu quero me tornar Ulisses. Eu quero visitar as terras conhecidas e desconhecidas, viver aventuras perigosas com o Ciclope e idílios adoráveis com Nausícaa. Quero jantar em casa do rei Alcínoo. Quero proporcionar-me a experiência universal possível com esses deslocamentos. Foi assim que um povo de marinheiros inventou a geometria e a filosofia (SERRES, 2007, p. 26. Grifos do autor).

Assim como foi a Odisseia para os gregos, podemos escolher referências-guia para servir a formação dos humanos na con- 
temporaneidade. Talvez a acumulação e pulverização das narrativas tornem o desafio maior do que o enfrentado pelos gregos. Edgar Morin se colocou nesse desafio de encontrar matrizes, orientações, caminhos. O seu caminho estrutura-se a partir de um exercício interminável de religação de saberes. Para ele, ao invés de conteúdos isolados por disciplinas, o ensino deveria se organizar por meta-temas capazes de aglutinar a multiplicidade das informações dispersas nos domínios especializados. Com esse propósito, Morin apresentou a constelação meta-temática Cosmo, Terra, vida, sociedade, homem, culturas adolescentes, história e arte como organizadores de uma reforma do ensino. As Jornadas Temáticas - evento coordenado por ele como contribuição à reforma do ensino fundamental na França, apresentado ao então Ministro da Educação Claude Alegré, no ano de 1998, expressa essa motivação.

Passados 22 anos das Jornadas, resta-nos saber como temos exercitado nossa missão de educar para a vida. De nossa perspectiva, a educação pode ser entendida como experimento máximo para as viagens do educador-autor que, imunizado contra uma pedagogia da fratura é contaminado pela carga viral transportada pela pedagogia complexa, aberta às incertezas dos mapas já confeccionados. Agora o educador-autor se embrenha nas variações descritivas que se acumulam na literatura, na ciência, na tradição.

Enredos cumulativos, dissimétricos ou descontínuos, mas sempre especulativos e invasivos, revelam formas sistemáticas de explorações de superfície e dos subsolos da Terra, criando a noção de uma "era planetária” (MORIN, 2002, p. 46). Pergunta Morin,

o que seria esse planeta, esse grão de poeira cósmica onde emergiu a vida, onde a vegetação produziu o oxigênio de sua atmosfera, onde o conjunto dos seres vivos, espalhando-se por toda a sua superfície, constituiu uma biosfera eco-organizada e auto-regulada, onde originada de um ramo do mundo animal, a aventura da hominização se lançou e se desenvolveu? (MORIN, 2002, p. 46). 
Para esse pensador errático, “a existência da Terra não é mais apenas de superfície, mas é profundidade. Ela não é mais estática, é evolutiva". Ele amplia esse argumento afirmando que "nossa crosta viveu e continua a viver uma aventura prodigiosa, feita de movimentos dissociativos, reassociativos, verticais, horizontais, de deriva, encontros, choques (tremores de terra), curtos-circuitos (erupções vulcânicas), quedas de grandes meteoritos, glaciações e aquecimentos” (MORIN, 2002, p. 47). Além disso, “a Terra é o berço da vida" (MORIN, 2002, p. 51). A Terra, esse organismo vivo e complexo, é apontada por Morin como um dos meta-temas para guiar uma reforma do ensino, devendo ser abraçado como tema-problema. Isso posto, há que se ocupar o educador em criar as pontes entre as diversas narrativas para tecer a religação do que está disperso, difuso, fragmentado. Esse é o desafio da nossa época, das ciências multidimensionais como a Geografia, das novas ciências sistêmicas como Ecologia, Ciências da Terra e Cosmologia.

Certamente a transmissão do que aprendemos é perene, com um certo privilégio para os conteúdos da cultura tecnocientífica, deixando no esquecimento narrativas literárias e ensinamentos dos saberes milenares sobre o mundo físico, a sociedade e a condição humana. Certamente, ainda persiste o ideário fragmentado para pensar a organização do conhecimento, muito embora reconheçamos tentativas de alteração dessa matriz do pensamento contemporâneo.

A recorrência feita por alguns segmentos educacionais em pensar a reforma como sendo um protocolo pragmático e pouco paradigmático tem contribuído para que as ideias de Morin sejam vistas como receitas aplicáveis em situações previamente idealizadas. Esse entendimento compromete o que Edgar destaca já no início do capitulo 1, do livro $A$ cabeça bem-feita. Para ele, o desafio do ensino está em lidar "com realidades ou problemas cada vez mais polidisciplinares, transversais, multidimensionais, transnacionais, globais, planetários" (MORIN, 2000, p. 13), o que requer tornar visíveis "os conjuntos complexos; as interações e retroações entre partes e todo; as entidades multidimensionais; os problemas essenciais" (MORIN, 2000, p. 
13). O que está em jogo é como pensamos a realidade, atribuindo a este pensamento a indissociável ação pertinente, afinal o real decorre da implicação pensamento/ação/ação/pensamento.

A questão dos saberes necessários à educação do futuro está amparada numa reforma paradigmática, sendo fundamental ao educador estar atento a uma agenda de múltiplos princípios: 1. Pensar a educação como uma atividade humana cercada de incertezas e indeterminações, mas também comprometida com os destinos das espécies, incluindo a humana, suas evoluções, regressões; 2. Praticar uma ética da competência que comporte ao mesmo tempo um pacto com o presente sem esquecer nosso compromisso com o futuro; 3. Buscar as conexões existentes entre o fenômeno que queremos compreender e o seu ambiente maior; 4. Abdicar da ortodoxia, das fáceis respostas finalistas e completas; 5. Exercitar o diálogo entre os vários domínios das especialidades; 6. Deixar emergir a complementaridade entre arte, ciência e literatura; 7. Transformar nossos ensinamentos em linguagens que ampliem o número de interlocutores da ciência. Tudo isso talvez seja um bom exercício para religar nas teorias, nos conhecimentos e na ciência os laços indissociáveis da teia da vida.

Ao educador imbuído desses princípios caberia, hoje, o exercício de fazer emergir uma qualidade do pensamento que está em parte adormecida: o prazer de conhecer. $\mathrm{O}$ incitamento à criatividade, o propósito de interditar a ortodoxia e a certeza, podem vir a prefigurar uma educação mais atenta às demandas culturais desse século. Esse educador talvez tenha que incluir na sua agenda duas tarefas que, mesmo distintas, são complementares. Uma diz respeito à reconstrução de seu próprio perfil enquanto profissional da educação: a morte do sujeito narcisicamente investido do poder é o mínimo que se espera para se reformatar os espaços discursivos do diálogo professor-aluno. Essa tarefa amplia-se numa outra, sem dúvida investida de maior envergadura e desafio. Trata-se de exercitar uma verdadeira aeróbica dos neurônios no sentido de desconstruir os imprintings paradigmáticos que impedem novas e ampliadas 
sinapses cognitivas de alunos cada vez mais ávidos em expor suas subjetividades, seus mapas auto-biográficos e em compreender os conteúdos disciplinares que se tornam significativos apenas pela partilha e co-produção.

\section{Para concluir}

Os argumentos, circunstâncias e reflexões expostas anteriormente, e sobretudo as referências feitas a Edgar Morin, permitem destacar uma das proposições fundamentais do pensamento complexo, isto é, a implicação do sujeito no conhecimento. Dessa proposição pode se inferir por consequência a implicação do autor na narrativa. Trata-se na verdade de: a) tomar consciência dessa implicação; b) relativizar o sentido da objetividade pretendido pela ciência, tanto quanto reduzir o sentimento de verdade absoluta; c) ampliar os diálogos intersubjetivos entre pesquisadores de modo a consolidar uma ecologia das ideias que garanta a singularidade e a diversidade das narrativas da ciência.

Se faz sentido propugnar por uma ciência da inteireza, supõe-se igualmente lançar as bases para uma educação que facilite a inteireza do sujeito. Nesse sentido, é importante redirecionar os horizontes pedagógicos e educacionais, com vistas à autoformação de sujeitos que se sintam autores de suas narrativas. Concebendo-se como construtores da realidade, os pesquisadores sentir-se-ão certamente responsáveis pelo discurso proferido e pela narrativa construída. Dessa perspectiva, a narrativa subjetivada e uma ciência da inteireza caminham lado a lado com uma ética da responsabilidade do cientista-educador.

Uma agenda a ser permanentemente refeita ou ampliada poderia se constituir num primeiro passo em direção a esse horizonte. Essa agenda poderia partir de quatro recomendações:

1. Disseminar e discutir com nossos alunos, livros, textos ou artigos que dessacralizem a ciência e as teorias; que mostrem o contexto, as contradições e as singularidades da vida dos autores consagrados e compreendidos como su- 
per-homens; que destaquem a relação de proximidade ou afastamento entre autor e obra, autor e tempo histórico.

2. Problematizar a separação entre obras teóricas, obras de divulgação e obras autobiográficas afim de considera-las como essencialmente complementares e não opostas e excludentes.

3. Para além da linguagem escrita, fazer uso de filmes que contextualizem a vida dos cientistas, compositores, escritores, tomando tais filmes como complementos das obras escritas e não como meras ilustrações.

4. Incentivar nos alunos uma escritura que evoque a autoria dos argumentos e expresse a responsabilidade e o compromisso do sujeito com as palavras; que reduza o mimetismo teórico e a repetição do que já foi demasiadamente repetido; que apele para a criatividade e singularidade das compreensões sobre o mundo.

Essa agenda, mesmo que incompleta e provisória, poderia ajudar a desfazer o equívoco de uma ciência abstrata, impessoal, neutra e objetiva. Poderia talvez alimentar a autoestima intelectual tão necessária à construção de sujeitos mais vivos e autônomos, verdadeiros artesãos do pensamento, da vida, da ciência e da história de cada dia. A reforma da educação requer, como afirmou Edgar Morin, a "regeneração de Eros".

\section{Referências}

ALMEIDA, M. C. Ciências da complexidade e educação: razão apaixonada e politização do pensamento. 2. ed. rev. ampl. Curitiba: APPRIS, 2017.

BACHELARD, G. O novo espírito científico. Tradução de Antônio José Pinto Ribeiro. Lisboa/Portugal: Edições 70, 2008.

HEISENBERG, W. A parte e o todo: encontros e conversas sobre física, filosofia, religião e política. Tradução Vera Ribeiro. Rio de Janeiro: Contraponto, 1996.

MARX, K. Manuscritos econômico-filosóficos. Tradução, apresentação e notas de Jesus Ranieri. São Paulo: Boitempo, 2010. 
MORIN, E. Ensinar a viver: manifesto para mudar a educação. Tradução de Edgard de Assis Carvalho e Mariza Perassi Bosco. Porto Alegre: Sulina, 2015.

MORIN, E. A cabeça bem-feita: repensar a reforma, reformar o pensamento. Tradução de Eloá Jacobina. 9. ed. Rio de Janeiro: Bertrand Brasil, 2004.

MORIN, E. O Método 5: a humanidade da humanidade: a identidade humana. Tradução de Juremir Machado da Silva. Porto Alegre: Sulina, 2002.

MORIN, E. A religação dos saberes: o desafio do século XXI. Tradução de Flávia Nascimento. Rio de Janeiro: Bertrand Brasil, 2001.

MORIN, E. Os sete saberes necessários à educação do futuro. Tradução de Catarina Eleonora F. da Silva e Jeanne Sawaya. 2. ed. São Paulo: Cortez; Brasília; UNESCO, 2000.

MORIN, E. Para sair do século XX. Tradução de Vera Azambuja Harvey. Rio de Janeiro: Nova Fronteira, 1986.

MORIN, E. Meus demônios. Tradução de Fernando Martinho. Portugal: Publicações Europa-América, 1995.

MORIN, E. O paradigma perdido: a natureza humana. 5. ed. Mens Martins: Europa-América, 1991.

MORIN, E.; CIURANA, E. R.; MOTTA, R. D. Educar na era planetária: o pensamento complexo como método de aprendizagem pelo erro e incerteza humana. Tradução de Sandra Trabucco Valenzuela. São Paulo: Cortez; DF: UNESCO, 2003.

SERRES, M. Filosofia mestiça. Tradução de Maria Ignez Duque Estrada. Rio de Janeiro: Nova Fronteira, 1993.

SERRES. M. Júlio Verne: a ciência e o homem contemporâneo. Tradução de Mônica Cristina Corrêa. Rio de Janeiro: Bertrand Brasil, 2007. 